\title{
Challenge to British forensic database
}

\section{London}

THE British civil rights group Liberty is seeking to take London's Metropolitan Police to the European Court of Human Rights, questioning the legality of its database of DNA fingerprinting results. Liberty's argument turns on the case of Roy Williams, a man questioned during a 1988 murder inquiry and subsequently cleared after voluntarily submitting a DNA sample for analysis - but who later found that his DNA profile had been included in the Metropolitan Police database without his consent. If taken up by the European Commission for Human Rights, the case may take as long as five years to resolve, but Liberty's action highlights a debate likely to gain momentum over the coming year, as national DNA profile databases come into general use in Britain and the United States. In Britain, the Home Office Forensic Science Service has set up a central database which police forces can ask to be trawled for matches to their scene-of-crime samples, and the Federal Bureau of Investigation (FBI) expects to have a similar US database in place a year from now.

John Wadham, Liberty's legal officer, complains that the police and forensic scientists in Britain are launching their DNA profile databases without waiting for a full public debate over what data should be included. He believes the establishment of databases should be governed by new legislation, pointing out

\section{Court favours mice, rats, birds}

\section{Washington}

RULING that any federal regulation that fails to include rats, mice and birds as laboratory animals is "arbitrary and capricious", a federal court last week directed the US Department of Agriculture (USDA) to reconsider its interpretation of the Animal Welfare Act. The decision is a victory for animal-welfare activists, who had argued that USDA had overstepped its authority in choosing to exclude rodents and birds when writing regulations for implementation of the act (see Nature 351, 338; 1991).

Although the animal welfare act is silent on the subject of rats, mice and birds, it explicitly lists dogs, cats, monkeys, guinea pigs, hamsters, rabbits "live or dead" for inclusion in its guidelines and also calls for the inclusion of "such other warmblooded animal" as the agriculture secretary finds is being used in research. The Secretary would not have to look far to find laboratory rats and mice in abundance.

In its defence, USDA had claimed that including the animals in its regulations would double or triple its inspection workload and force the agency to spend several million dollars to increase its staff. Officials have often argued that there is little evidence that laboratory rodents and birds - which, combined, make up more than 80 per cent of all laboratory animals - are being generally mistreated or kept in substandard housing. They point out that the animals are already covered by the guidelines of the Public Health Service (PHS), which funds most of the academic animal laboratories in the United States. Because rodents are so often used in research and so easily maintained, standard and humane caging is the norm, USDA says.
Animal welfare groups, including the Humane Society and the Animal Legal Defense Fund, which were both parties in the lawsuit, do not think that abuse of rats and mice is widespread. But they are concerned that no one is inspecting the facilities to watch for the exceptions. Because the PHS guidelines are not formal regulations like the Animal Welfare Act, the health service depends on institutions to police themselves.

In the decision, federal judge Charles Richey wrote that he "recognizes that enforcement of these regulations would require some expenditure of agency resources. Yet...the inclusion of rats, mice and birds under the Act would send an important message to those responsible for their care - that the care of these animals is something for which they are legally responsible...". He noted that USDA has not asked Congress for more money to expand its inspection programme; in fact, USDA once tried to have it eliminated.

If, as expected, USDA does modify its rules to include rats, mice and birds, most laboratories will have little trouble complying, says Barbara Rich, vice president of the National Association for Biomedical Research, an animal research lobby group. Rather than devise new standards for animal enclosures, USDA will probably just adopt the PHS guidelines as law, something it did with primates, dogs, cats and other research animals. Extending those rules to rats and mice "would mean some different record-keeping and reporting [procedures], but I don't see it as a big problem," Rich says. USDA has not decided if it will appeal the decision.

Christopher Anderson that, under the Police and Criminal Evidence Act, conventional fingerprint evidence must not be kept on file if a suspect is not convicted.

According to the Home Office (Britain's equivalent of an interior ministry), the Forensic Science Service computer database contains DNA profiles from convicted criminals and those collected during investigations that have not yet come to trial or which relate to unsolved crimes. After a trial, only the DNA profiles from those suspects who are convicted will remain in the computer - although a spokeswoman says that paper files may be retained. (British law provides far greater controls over the confidentiality of computer-held information than over paper records, but Wadham says the distinction is "irrelevant".)

Wadham says that the separate Metropolitan Police database seems to have been set up without even the rudimentary controls exercised by the Forensic Science Service: when he visited the force's Scotland Yard headquarters to ensure that Williams' DNA test results were deleted, Wadham says that that the police found it necessary to call in a computer specialist; the system did not seem to have been set up to allow for the deletion of test results collected from innocent suspects. For their part, the Metropolitan Police refuse even to confirm that they possess a computerized DNA profile database.

John Hicks, head of the FBI's crime laboratory in Washington, is less worried about legal challenges to his agency's planned database. Only two classes of information will be included, he says: the DNA profiles of convicted felons, and crime scene evidence from cases that are still under investigation. Hicks adds that, by the time the FBI database comes into general use, it may have legislative backing. Representative Don Edwards' (Democrat, California) wide-ranging bill on forensic DNA testing (see Nature 351, $684 ; 1991$ ), which would authorize the FBI to establish a DNA profile database, has now been passed by the House of Representatives.

Although the bill's progress is temporarily blocked by controversy surrounding other crime-related legislation to which it has become attached, Hicks believes it will be soon be separated from the other measures, and passed into law. The situation in the United States could become more complicated if state and city authorities decide - like the Metropolitan Police in Britain - to set up their own DNA profile databases, but Hicks says he knows of no such plans.

Peter Aldhous 